\title{
Editorial
}

\section{Cheryl Desha}

Associate Professor, Griffith University, Australia

There is an urgent need to improve the resilience of infrastructure assets, including road, rail, marine, power and telecommunication networks, which provide critical services for life in the $21 \mathrm{st}$ Century. Around the world this spans the diversity of needs within 'mega cities' through to providing 'lifelines' from cities through to regional and remote developments. Natural disasters such as wildfire, earthquakes, tornados, floods and hurricanes affect the serviceability of infrastructure assets, and are becoming more intense and frequent in many parts of the world (IPCC, 2021; UN, 2020). Human-induced events such as explosions or accidents can also trigger disaster events, which can then lead to infrastructure operability interruptions and asset failures.

Civil engineers will have a crucial role to play in this evolving 'resilient infrastructure' agenda over the next two decades, and adjust design approaches, tools and decision-making processes to optimise the operability, safety and accessibility of infrastructure assets and networks with disasters in mind. This includes modelling and preventative measures in anticipation of disasters (Hasan and Foliente, 2015) and enabling effective 'build back better' betterment program delivery post-disasters (Chester et al., 2021). In 2015, the United Nations (UN) published the Sendai Framework for Disaster Risk reduction, which provides a useful reference for improving asset management practices and planning locally appropriate maintenance and betterment actions to improve infrastructure resilience (UNDRR, 2015). Australia's national infrastructure plan (IA, 2021) is an example of a practical and actionable roadmap for resilient infrastructure reform in the face of disasters and pandemic disruptions, which could address a number of the United Nations Sustainable Development Goals (UN, 2015).

In 2020, the International Asset Management Editor in Chief Arun Kumar (RMIT University, Australia) convened an international team to seek and review papers on this topic, including Cheryl Desha (Griffith University, Australia), Greg Foliente (University of Melbourne, Australia), Shafiq Alam (Queensland Department of Transport and Main Roads, Australia), Mark Rudrum (Arup, UK), Kieran Tully (CIRIA, UK), and Xiomara Sanchez-Castillo (University of New Brunswick, Canada).

This resultant themed issue on 'resilient infrastructure for improved disaster management' brings together several examples of road and transportation infrastructure research projects, where colleagues are working to manage infrastructure assets amid changing climatic conditions and societal demands.

The first and second papers form a two-part presentation of the key findings from a European study into the 'Future Proofing Strategies for Resilient Transport Networks against Extreme
Events' (Foresee). In the first paper (Adey et al., 2021), the authors present the methodology developed to measure and set targets for the resilience of transport systems in a variety of extreme event situations. In the second paper (Martani et al., 2021) the authors use a worked example to discuss how critical transport infrastructure can be managed to provide acceptable levels of service in extreme events.

In the third paper (Sahoo et al., 2021) the authors provide an industry-facing paper on lessons learned in India regarding climateresilient road infrastructure in coastal areas subjected to cyclones and associated floods. They describe a detailed reconnaissance study and technical assessment of transportation infrastructure and provide recommendations for possible preventative design measures for improved road infrastructure outcomes in these locations.

In the fourth paper (Caldera et al., 2021), the authors focus on the opportunity to improve the evidence-base for road infrastructure capital works and maintenance prioritisation. The 15 parameters for evaluating road infrastructure resilience using the four disaster management phases of 'prevent, prepare, respond, recover' provide a practical decision-support framework for knowing what data is important to collect and analyse and at what time, to ensure capital works and maintenance budgets can enable resilient infrastructure outcomes.

We hope that this special issue brings attention to the topic of managing infrastructure to play a role in disaster management, engaging academics, researchers, and industry practitioners to share new knowledge about practical solutions to current and future challenges.

Associate Professor Cheryl Desha is Theme Leader for the 'Digital Earth and Resilient Infrastructure'research agenda, Cities Research Institute (CRI) and Engagement Director (Industry) for the School of Engineering and Built Environment, Griffith University (South East Queensland, Australia).

\section{REFERENCES}

Adey BT, Martani C, Kielhauser C et al. (2021) Estimating, and setting targets for, the resilience of transport infrastructure. Infrastructure Asset Management 8(4): 167-190, https://doi.org/10.1680/jinam.20.00011.

Caldera S, Mostafa S, Desha C and Mohammed S (2021) Integrating disaster management planning into road infrastructure asset management. Infrastructure Asset Management 8(4): 219-233, https:// doi.org/10.1680/jinam.21.00012.

Chester M, El Asmar M, Hayes S and Desha C (2021) Post-Disaster infrastructure delivery for resilience. Sustainability 13(6): 3458 , https://doi.org/10.3390/su13063458. 
Hasan S and Foliente G (2015) Modelling infrastructure system interdependencies and socioeconomic impacts of failure in extreme events: emerging R\&D challenges. Natural Hazards 78(3): 2143 2168, https://doi.org/10.1007/s11069-015-1814-7.

IA (Infrastructure Australia) (2021) 2021 Australian Infrastructure Plan. IA, Sydney, Australia. See https://www.infrastructureaustralia. gov.au/publications/2021-australian-infrastructure-plan (accessed 23/11/2021)

IPCC (Intergovernmental Panel on Climate Change) (2021) The Sixth Assessment Report - The Numbers Behind the Science. IPCC, Geneva, Switzerland. See https://www.ipcc.ch/assessment-report/ar6/ (accessed 23/11/2021)

Martani C, Adey BT, Robles I et al. (2021) Estimating the resilience of, and targets for, a transport system using export opinion. Infrastructure Asset Management 8(4): 191-208, https://doi. org/10.1680/jinam.20.00029.
Sahoo U, Dash SR and Sahu CS (2021) Climate-resilient road design in coastal areas subjected to cyclones and associated floods. Infrastructure Asset Management 8(4): 209-218, https://doi. org/10.1680/jinam.21.00010.

UN (United Nations) (2015) Transforming Our World: the 2030 Agenda for Sustainable Development. A/RES/70/1. UN General Assembly, New York, NY, USA. See https://www.refworld.org/docid/57b6e3e44. html (accessed 23/11/2021).

UN (2020) Decade of Action: 10 Years to Transform our World. UN, New York, NY, USA. See https://www.un.org/sustainabledevelopment/ decade-of-action/ (accessed 23/11/2021).

UNDRR (United Nations Office for Disaster Risk Reduction) (2015) Sendai Framework for Disaster Risk Reduction 2015-2030.

UNDRR, Geneva, Switzerland. See https://www.undrr.org/ publication/sendai-framework-disaster-risk-reduction-2015-2030 (accessed 23/11/2021). 